\title{
USING HYDROGEOCHEMICAL AND ECOHYDROLOGIC RESPONSES TO UNDERSTAND EPIKARST PROCESS IN SEMI-ARID SYSTEMS, EDWARDS PLATEAU, TEXAS, USA
}

\author{
UPORABA HIDROGEOKEMIČNIH IN EKOHIDROLOŠKIH \\ ODZIVOV ZA RAZUMEVANJE EPIKRAŠKIH PROCESOV V \\ POLSUŠNIH SISTEMIH, PLANOTA EDWARDS, TEKSAS, ZDA
}

\author{
Benjamin F. SCHWARTZ ${ }^{*}$, Susanne SCHWINNING ${ }^{1}$ Brett GERARD ${ }^{1}$, Kelly R. KUKOWSKI ${ }^{1}$, \\ Chasity L. STINSON ${ }^{1} \&$ Heather C. DAMMEYER ${ }^{1}$
}

\begin{abstract}
UDC 556.32:581.11(736.4)

Benjamin F. Schwartz, Susanne Schwinning, Brett Gerard, Kelly R. Kukowski, Chasity L. Stinson \& Heather C. Dammeyer: Using hydrogeochemical and ecohydrologic responses to understand epikarst process in semi-arid systems, Edwards plateau, Texas, USA

The epikarst is a permeable boundary between surface and subsurface environments and can be conceptualized as the vadose critical zone of epigenic karst systems which have not developed under insoluble cover. From a hydrologic perspective, this boundary is often thought of as being permeable in one direction only (down), but connectivity between the flow paths of water through the epikarst and the root systems of woody plants means that water moves both up and down across the epikarst. However, the dynamics of these flows are complex and highly dependent on variability in the spatial structure of the epikarst, vegetation characteristics, as well as temporal variability in precipitation and evaporative demand. Here we summarize insights gained from working at several sites on the Edwards Plateau of Central Texas, combining isotopic, hydrogeochemical, and ecophysiological methodologies. 1) Dense woodland vegetation at sites with thin to absent soils $(0-30 \mathrm{~cm})$ is in part supported by water uptake from the epikarst. 2) However, tree transpiration typically becomes water-limited in dry summers, suggesting that the plant-available fraction of stored water in the epikarst depletes quickly, even when sustained cave drip rates indicate that water is still present in the epikarst. 3) Flow paths for water that feeds cave drips become rapidly disconnected from the evaporation zone of the epikarst and out of reach for plant roots. 4) Deep infiltration and recharge does not occur in these systems without heavy or continuous precipitation that exceeds some threshold value. Thresholds are strongly correlated with antecedent potential evapotranspiration and rainfall, suggesting control by the moisture status of the epikarst evapotranspiration zone. The epikarst and unsatu-
\end{abstract}

Izvleček UDK 556.32:581.11(736.4)

Benjamin F. Schwartz, Susanne Schwinning, Brett Gerard, Kelly R. Kukowski, Chasity L. Stinson \& Heather C. Dammeyer: Uporaba hidrogeokemičnih in ekohidroloških odzivov za razumevanje epikraških procesov $v$ polsušnih sistemih, planota Edwards, Teksas, ZDA

Epikras je prepustna meja med površinskim in podzemeljskim okoljem in se lahko pojmuje kot vadozno kritično območje epigenih kraških sistemov, ki se pod netopnim pokrovom ne razvijajo. Iz hidrološkega vidika je to območje pogosto pojmovano kot prepustno le v eno smer (navzdol), vendar povezave med vodnimi potmi skozi epikras in koreninskimi sistemi lesnatih rastlin pomenijo, da se voda premika navzgor in navzdol po epikrasu. Vendar pa je dinamika teh tokov zapletena in zelo odvisna od spremenljivosti v prostorski strukturi epikrasa, značilnosti vegetacije, kot tudi v časovni spremenljivosti padavin in izhlapevanja. Tukaj povzemamo spoznanja iz raziskav na več mestih na planoti Edwards v osrednjem Teksasu, ki združuje izotopske, hidrogeokemične in ekofiziološke metodologije. 1) Gosta gozdna vegetacija na golih mestih ali mestih s tanko prstjo $(0-30 \mathrm{~cm})$ deloma črpa vodo iz epikrasa. 2) Vendar pa je drevesna transpiracija običajno prekinjena $\mathrm{v}$ času suhih poletij, kar kaže, da se rastlinam dostopen del uskladiščene vode v epikrasu izčrpava hitro, tudi ko trajno kapljanje $\mathrm{v}$ jamah še nakazuje, da je voda še vedno prisotna v epikrasu. 3) Vodne poti, ki napajajo kapljanje $\mathrm{v}$ jamah so hitro prekinjene in izven dosega rastlinskih korenin. 4) Globoka infiltracija in polnjenje teh sistemov ni efektivno brez močnih in stalnih padavin, ki presegajo določeno mejno vrednost. Pragovi so močno povezani s predhodno potencialno evapotranspiracijo in padavinami, kar kaže na odvisnost od stopnje vlage v območju epikraške cone evapotranspiracije. Epikras in nezasičena cona sta $v$ tej regiji lahko pojmovani kot spremenljivo nasičen sistem $\mathrm{s}$ skladiščenjem $\mathrm{v}$ razpokah, poroznem mediju in $\mathrm{v}$ plitvih visečih vodonosnikih. Večina teh je drevesnemu koreninskemu

\footnotetext{
${ }^{1}$ Texas State University, Department of Biology, 601 University Drive, San Marcos, TX 78666

*corresponding author: e-mail: bs37@txstate.edu
}

Received/Prejeto: 23.2.2013 
rated zone in this region can be conceptualized as a variably saturated system with storage in fractures, matrix porosity, and in shallow perched aquifers, most of which is inaccessible to the root systems of trees, although woody vegetation may control recharge thresholds.

Keywords: hydraulic disconnection, precipitation thresholds, root zone, plant water use, recharge, epikarst storage, barometric pressure. sistemu nedostopna, čeprav lahko lesna vegetacija nadzira mejne vrednosti polnjenja.

Ključne besede: hidravlična prekinitev, pragovi padavin, koreninska cona, rastlinska uporaba vode, polnjenje, skladiščenje v epikrasu, zračni tlak.

\section{INTRODUCTION}

The Critical Zone is "the thin veneer of Earth that extends from the top of the vegetation to the base of weathered bedrock ... where fresh water flows, soils are formed from rocks, and terrestrial life flourishes"(NSF 2012). As an integrated system, the Critical Zone is poorly understood in general, but especially so in systems where the transition from soil to soluble bedrock materials is blurred by the dominance of a wide hybrid zone, part soil and part fractured, weathered, and porous bedrock. These transition zones are commonly found in regions where karst is exposed at the surface and are known as the 'epikarst' (Jones et al. 2003).

Unlike horizons of weathered non-soluble bedrock beneath soils, the epikarst is a complex network of rock matrix, empty cavities, soil pockets and flow paths of variable hydraulic conductivity (Klimchouk 2004; Estrada-Medina et al. 2013). Importantly, the epikarst also contains plant roots. Thus, the epikarst not only facilitates the transport of surface water and chemical constituents to underlying aquifers, it also stores water, transforms organic and inorganic materials, and makes water and nutrients available for uptake by plants. In short, the epikarst is a highly dynamic boundary between surface and groundwater environments that modifies, and is modified by, the transfer of water.

The hydrologic function of the epikarst has been studied using a variety of methods ranging from basinwide studies (e.g., Mangin 1975; Williams 1983) to incave studies of drips and inlets. Studies at both scales have concluded that the epikarst is an important storage component in karst systems and that the hydraulic properties of the epikarst are substantially different from those of the underlying conduit-dominated flow and transport system (e.g., Smart \& Friederich 1986; Lee \& Krothe 2001; Arbel et al. 2010). Comparatively, the epikarst has higher storage, variably saturated conditions, higher fracture density, and relative homogeneity of hydraulic flow pathways.

One aspect that has received relatively little attention is the interaction between epikarst and vegetation
(Schwinning 2010). Trees and shrubs take up water and nutrients from the epikarst and by doing so, influence the dynamics and chemical composition of water draining out of the epikarst. The few existing studies suggest that root access to water stored in the epikarst is extremely heterogeneous; probably constrained by the sizes and distribution of conduits and the durability of weathered rock. Studies from karst areas in seasonally dry climates of Mexico, China, and the USA suggest limited use of epikarst water by trees, chiefly to supplement water during the dry season, but not enough to completely alleviate water stress (Querejeta et al. 2006; Querejeta et al. 2007; Schwinning 2008; Nie et al. 2011; Rong et al. 2011; Deng et al. 2012; Kukowski et al. 2013). In addition, these studies showed that rooting depth and depth of water uptake vary by species and with the age of individuals. With few exceptions, the stable isotope ratio analysis of water extracted from woody plants suggested relatively shallow, evaporatively enriched water sources in the epikarst. At an epikarst site on the Edwards Plateau of Central Texas, USA, variation in precipitation-adjusted annual evaporation was more strongly tied to soil depth than to tree density (Heilman et al. 2009). So far, only one study in the Balcones Fault Zone of the Edwards Plateau of Central Texas, USA, found roots tapping directly into deep conduits in the phreatic zone at $25-30 \mathrm{~m}$ depth (Jackson et al. 1999), and this situation seems to be the exception rather than the rule.

In this paper, we summarize findings from three sites in central Texas, USA, where we combined methods from hydrogeology, geochemistry, ecohydrology and statistical modeling to characterize the epikarst as a complex, dynamic storage system, interacting with surface vegetation. Our overall goal was to determine the degree of hydrological coupling between different components of the 'Critical Zone', including woody vegetation at the surface, a thin layer of soil, the epikarst, and rates of epikarst drainage as estimated from speleothem drip rates inside caves. 
Our primary research questions were: 1) where are the water sources for forest trees located in the soil to bedrock continuum and, consequently, how does tree water use likely affect deep infiltration and recharge in the Edwards Plateau, 2) how do environmental parameters control infiltration and recharge, and 3) can hydrogeochemical data recorded inside caves be used to refine conceptual models of epikarst form and function? To answer these questions, we used a variety of measurements, including liquid water stable isotopes and sap-flow to determine the source of tree water, and cumulative potential evapotranspiration and precipitation data to determine precipitation thresholds required for groundwater recharge. Finally, through comparing three sites with slightly different geologic and hydrological characteristics, two in Edwards limestone, one in Lower Glen Rose Limestone, we also aimed to examine the influence of geologic factors on these hydrologic processes.

\section{SITE DESCRIPTIONS}

Our study sites are located in the Hill Country of Central Texas, USA. The first, McCarty Cave, is just south of the city limits of San Marcos, TX. This shallow cave lies $3-10 \mathrm{~m}$ beneath a forested area dominated by cedar elm (Ulmus crassifolia), escarpment live oak (Quercus fusiformis), and Ashe juniper (Juniperus ashei), with fewer numbers of Texas persimmon (Diospyros texana), netleaf hackberry (Celtis laevigata var. reticulate), and agarita (Berberis trifoliolata). Soils are shallow and rocky, ranging from 0 to $30 \mathrm{~cm}$, and overlie epikarst formed in the Edwards limestone within the recharge zone of the Edwards aquifer, a confined aquifer that supplies fresh water to 2 million people between Austin and San Antonio along the Balcones fault zone. A domestic well was available for sampling $50 \mathrm{~m}$ from the cave.

The second site is Cave Without A Name (CWAN), approximately $17 \mathrm{~km}$ northeast of Boerne, TX. This commercial cave lies 15 to $30 \mathrm{~m}$ below the surface, and is formed in the lower Glen Rose Limestone, which comprises the upper part of the Middle Trinity group in the extensive Trinity Aquifer system underlying much of the Central Texas Hill Country (Veni 1994; Mace et al. 2000). The Trinity Aquifer is important not only for groundand surface water resources in the Hill Country, but it also contributes substantially to the Edwards Aquifer via cross-formational flow along the Balcones Fault Zone
(Kuniansky and Holligan 1994). Vegetation and soil type and thickness were similar to McCarty Cave, but the site had greater tree diversity, including two more species of oak, both deciduous: Texas oak (Quercus texana) and shin oak (Quercus sinuata). CWAN also contains a hydrologically active branchwork stream system containing $4.5 \mathrm{~km}$ of nearly water-filled main stem and tributary conduits. Exploration continues in the upstream reaches of the system.

The third site is Headquarters Cave on Camp Bullis, north of San Antonio. This cave lies beneath a hillside, and is formed across the contact zone between the Edwards and underlying Upper Glen Rose Limestones. The overstory vegetation is composed chiefly of escarpment live oak and Ashe juniper, and understory vegetation, soil characteristics and thickness are similar to the other two sites. However, just prior to this study, nearly all juniper trees were removed from a ca. $2,800 \mathrm{~m}^{2}$ area overlying and surrounding the cave.

The region is classified as having semi-arid to subtropical climate. Mean annual precipitation (1961-1990) in San Marcos, TX is $\sim 864 \mathrm{~mm} \pm 100 \mathrm{~mm}$ (http://www. wrcc.dri.edu/precip.html), which is similar to the Boerne and San Antonio areas. Mean August maximum temperature is $35^{\circ} \mathrm{C}$ and mean January minimum is $4^{\circ} \mathrm{C}$ (Dixon 2000).

\section{METHODS}

At each site, a suite of instruments was installed and data collected continuously at 10 or 15 minute intervals. Surface instrumentation included a full weather station (precipitation, wind speed and direction, solar radiation, temperature, and relative humidity; Onset Computer Corp., Bourne, MA, USA), two pairs of EC-5 soil mois- ture sensors (Decagon Devices, Inc., Pullman, WA, USA) at 15 and $25 \mathrm{~cm}$ depths, and sap flow sensors on all major tree species (one sensor per tree; six trees per species).

Inside the caves, conduits and speleothem drip sites were instrumented to measure drip rate or discharge, specific conductivity and temperature of drip water, and 
air temperature, which were reported to Hobo dataloggers (Micro Station H-21-002, Onset Computer Corp., Bourne, MA, USA) or recorded on Schlumberger CTD Diver instruments. At CWAN, 6 sites were monitored, including dripping speleothems formed on porous ceilings (2), dripping speleothems connected to small fractures (2), a small conduit that discharged water only after heavy precipitation and overland flow, and the cave stream. Drip water was collected on tarps and funneled into tipping-bucket rain gauges. Conduit and stream discharges were measured at weirs using paired pressure transducers and barometric pressure loggers, and stage-discharge relationships that allow measured water depth (stage) to be converted to discharge in units of L/s. At McCarty Cave, the well and two adjacent drip sites were monitored. Waters dripped directly from two sites on the porous bedrock ceiling with surface areas of 3 and $1 \mathrm{~m}^{2}$, respectively. In Headquarters Cave, one dripping speleothem was monitored at the bottom of the cave.

At all sites, water samples were periodically collected (hourly to monthly, depending on site and hydrologic conditions) for analysis of major ions, dissolved nutrients, and liquid water stable isotopes. Precipitation was also collected at all caves.
Granier type sap flow sensors (Granier 1985) were inserted $1 \mathrm{~cm}$ deep into the sapwood approximately at breast height and the trunk wrapped in reflective bubble insulation to reduce temperature artifacts. This method measures the velocity of sap flow rise in trees during the day, which is considered a relative measure of wholetree transpiration rate. On the same trees, pre-dawn leaf water potentials were periodically measured using a Scholander pressure chamber (Model 1000, PMS Instruments, Albany, OR, USA) and stem samples taken after dawn for the stable isotope ratio analyses of stem water. Stem samples were stored in screw cap vials and stored frozen before being cryogenically extracted under vacuum pressure (Ehleringer et al. 2000). Extracted stem, precipitation, and cave water samples were analyzed on an LGR DLT-100 Liquid Water Stable Isotope Analyzer (Los Gatos Research, Inc., Mountain View, CA, USA) with internal standards created using the LGR certified standards. Values are expressed in standard delta notation relative to the V-SMOW standard (Gonfiantini 1978). Precision was estimated at 0.5 per mil for $\delta D$ and 0.3 per mil for $\delta^{18} \mathrm{O}$ (one standard deviation).

Statistical analyses were performed using JMP and R software packages (JMP 1989-2007; R Development Core Team 2012).

\section{RESULTS AND DISCUSSION}

\section{TREE WATER SOURCES AND}

TRANSPIRATION RATE

We applied two methods to deduce the likely water sources of trees: We measured stable isotope ratios of extracted stem water and compared them with precipitation and drip water samples to identify (or rule out) water sources. This technique relies on the fact that plant water uptake by roots and pressure-driven flow through the sapwood does not involve isotopic fractionation (Ehleringer et al. 2000). Therefore, stem water, if sampled far upstream from evaporation sites (e.g., leaves), is considered a volume-weighted linear mixture of all plant water sources. Additionally, we measured the seasonal dynamics of sap water rise through trees and compared it to the dynamics of soil moisture and epikarst drainage rates to determine whether tree transpiration was more closely linked with the pulse dynamics of the soil and shallow epikarst, or the dampened dynamics of deeper water stores.

Comparison of isotope ratios ruled out cave drip, stream, or well water as a possible source of water for trees. During the summer drought of 2009, neither at the McCarty Cave site nor at Camp Bullis were drip water sources a likely source; instead, extracted sap water indicated evaporatively enriched water sources, implying that soil and the top of the epikarst were the predominant water sources. At McCarty Cave, sap water became progressively more enriched during the summer drought and farther removed from the local meteoric water line (Fig. 1). This suggests that the origin of the transpiration flux was precipitation stored relatively close to the surface, subjected to direct evaporation, and diminishing over the course of summer. At Camp Bullis, evaporative enrichment was not as extreme, indicating that trees had access to more stable, deeper water sources (Fig. 1). Accordingly, minimal predawn water potential values measured in August for Ashe juniper and live oak were lower at the McCarty Cave site than at Camp Bullis (live oak: $-4.2 \mathrm{MPa} \pm 0.4$ se (McCarty) vs. $-3.1 \mathrm{MPa} \pm 0.3$ se (C. Bullis); Ashe juniper: $-8.03 \mathrm{MPa} \pm 0.08$ se (McCarty) vs. -7.1 MPa \pm 0.2 se (C. Bullis)).

After the first substantial rainfall events in September $2009(70 \mathrm{~mm})$, stem water isotope ratios at the McCarty Cave site moved back towards the Local Meteoric Water Line (LMWL) and precipitation values, and 


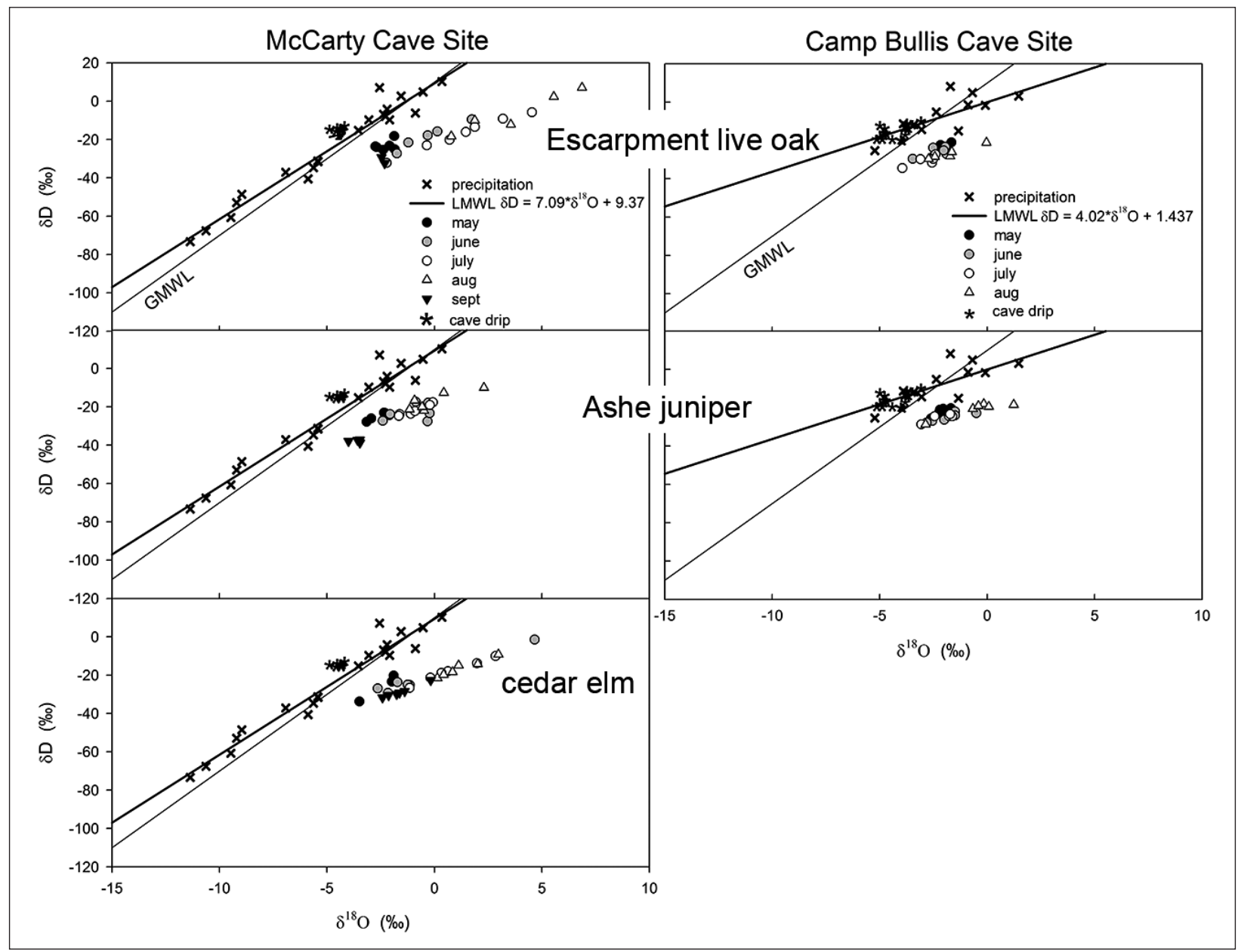

Fig. 1: Monthly liquid water stable isotope data from stem water extractions for three tree species at McCarty Cave (left panel) and two species at Headquarters Cave (right panel) showing evaporative enrichment over the summer drought of 2009. Stem water isotopes return to near starting values after $\sim 70 \mathrm{~mm}$ of precipitation in early September, 2009.

plant water potentials recovered immediately (data not shown), indicating once again that trees responded to soil and shallow epikarst water. Overall, deeper epikarst water could be ruled out as a likely source for transpiration, since mean drip isotope values, presumed to be a sample of water stored in the lower epikarst, did not correspond to tree water isotope ratios at any time, not even immediately after a rain event. This, combined with the fact that the isotope ratios of stem waters were highly variable according to meteorological conditions, while those of the drips were not, underscores our conclusion that the water available to the trees is largely separate from the (presumably deeper) sources supplying water to the drips.

Sap flow velocity (indicative of tree transpiration) declined rapidly during the month of May 2009 at both sites. However, rates of decline were different for different species, and there were also differences between sites (Fig. 2). At the McCarty Cave site, live oak transpiration declined most rapidly during the month of June, while Ashe juniper transpiration declined gradually over the entire summer. By contrast, at Camp Bullis, transpiration of Ashe juniper declined more rapidly than of live oak. This may have been because live oak was deeper-rooted than juniper at this site, with greater access to relatively more stable water sources at depth. This interpretation is also consistent with the stable isotope and water potential data. Escarpment live oak can grow deeper roots than Ashe juniper, if given a chance (Jackson et al. 1999). However, at McCarty Cave, there may not have been a chance, due to the less fractured rock substrate (Kukowski et al. 2013). Where some parts of the cave are just 4 $\mathrm{m}$ below ground, we saw no tree roots protruding from the ceiling, suggesting that the maximum rooting depth was $4 \mathrm{~m}$ at most, and probably much less. A trenching study in the same region showed that, irrespective of soil depth, most tree roots are no deeper than $40 \mathrm{~cm}$, although a few individual roots were observed to penetrate 


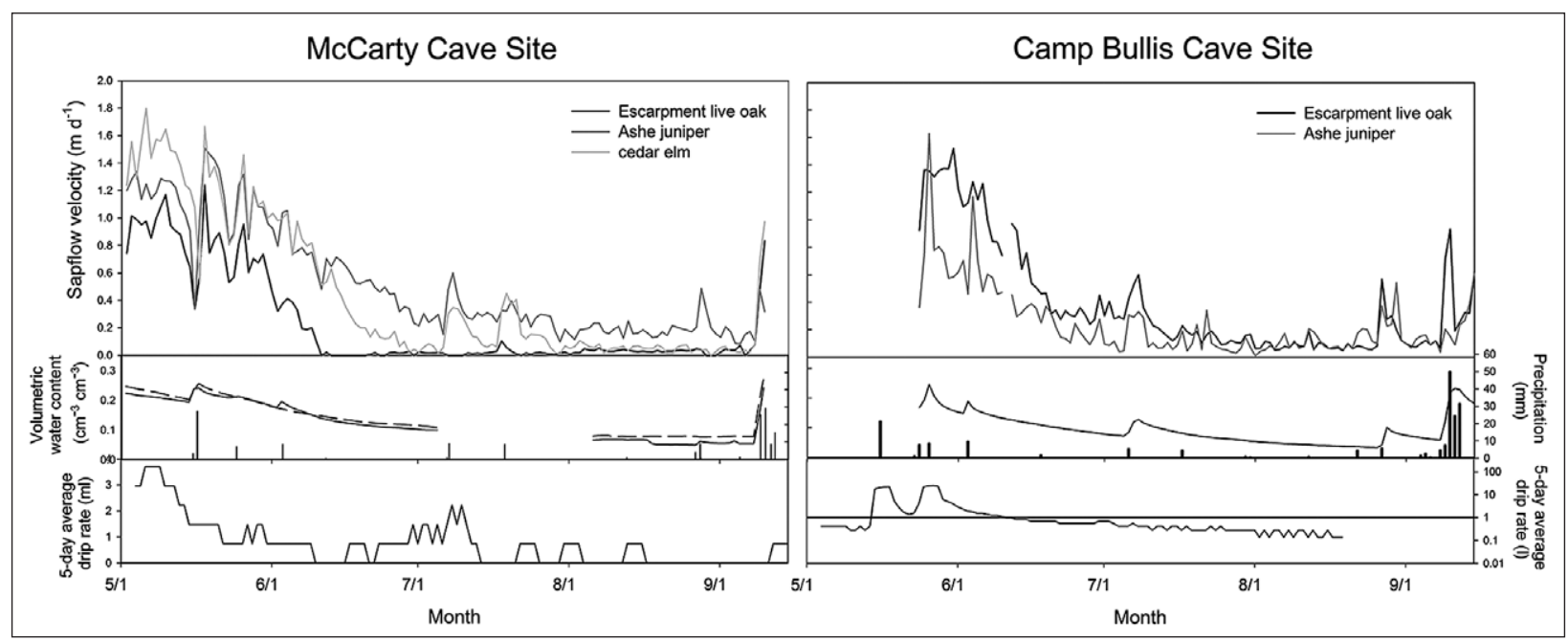

Fig. 2: Relationships between sap flow rates, soil moisture at $15 \mathrm{~cm}$ (solid line) and $25 \mathrm{~cm}$ (dashed line), precipitation, and drip rates at in-cave sites, for McCarty Cave and Headquarters Cave during the 2009 drought. Soil data were lost for a period of 1 month at McCarty Cave.

deeper through rock fissures (Heilman et al. 2009). Thus, it appears that live oak may have escaped more severe water stress at Camp Bullis by having a few roots penetrate deeper into the epikarst compared to Ashe juniper, although even these deeper water sources appeared to decline over the course of summer of 2009 (Fig. 2b).

At both cave sites, sap flow velocities followed similar dynamics as soil moisture; both were declining from spring into summer, but remained responsive to midsummer rain events. While in-cave drip rates were also declining over the same interval, there were also some differences relative to sap flow rates. At McCarty Cave, the steepest decline in drip rates was observed in May, at least a month ahead of the most precipitous decline in sap flow. This may indicate that epikarst storage was already low going into the spring of 2009, so that after rainfall events in spring, there was more water close to the surface than stored deeper in the epikarst. Drip rates increased slightly after a midsummer rain event, but were generally extremely low after May. In fact, the intermittent increase in drip rate could have been caused by an influx of moist air, which temporarily increased rates of condensation on the cave ceiling. At Camp Bullis, two large discharge pulses dominated drip rates in May, and from then on drip rates gradually declined, largely in parallel with the decline of transpiration. However, drip rates did not respond to the two mid-summer rain events, indicating a greater degree of separation between surface and lower epikarst dynamics. It is of note that sap flow in escarpment live oak, at both sites, seemed most closely linked to drip dynamics, following the early decline in drips rate at McCarty Cave and a more gradual decline at Camp Bullis Cave. This may indicate a greater reliance of this species on water stored closer to the bottom of the epikarst.

We conclude that tree transpiration is generally inseparable from moisture dynamics close to the surface, where water is stored in soil and soil pockets that are easily accessed by plant roots. Accessibility by roots to water from lower reaches of the epikarst may vary greatly with epikarst characteristics, but appears to be rare overall, except when specific site and epikarst conditions are met. For example, roots can access deeper epikarst water sources in situations where deeper or larger fractures and/or faults allow vertical penetration of several meters or more. Relatively dense woodlands seem possible across epikarst types in the Texas Hill Country, as this region has experienced wide-spread woody encroachment in the past 100 years (Van Auken 2000). However, we observed during the exceptionally severe drought of 2011 that local tree mortality rates differ greatly with epikarst characteristics. For example, at the McCarty Cave site, one third of all live oak trees and $6 \%$ of juniper trees died in 2011 (Kukowski et al. 2013), but at the Camp Bullis Cave site almost all trees survived. Thus, under extreme drought conditions, when all near-surface stores of water have dried up, trees may survive by having at least a few roots tap into remaining water pools deeper in the epikarst, provided that these pools exist and local geologic conditions permit root penetration.

We believe that a significant portion of storage supplying drips is in the rock matrix and fine fractures, which are largely inaccessible to plant roots. Cretaceous aged carbonates in the Hill Country have relatively high primary and secondary porosity when compared to $\mathrm{Pa}$ leozoic carbonates of the USA and elsewhere, and have 
many weathered and/or clay-rich beds which contain visible or palpable moisture when drilled or broken even during severe drought. This source of water in the epikarst may be either completely severed from the reach of plant roots, or may serve as a significant source of transpiration only under the most extreme drought conditions, after all other sources have been depleted.

Together with other lines of evidence (Heilman et al. 2009), our data contribute to the growing body of literature showing that trees in the Texas Hill Country, and in similar karst areas worldwide, have little capacity for utilizing deeper groundwater, and rely instead upon limited and rapidly depletable shallow water sources in the soil and upper epikarst, and their evolved abilities to survive frequent drought through drought tolerance or avoidance.

The hydraulic disconnection between surface and subsurface: how quickly does it form, and what precipitation thresholds must be overcome before recharge occurs?

Drip and discharge data from our in-cave sites clearly illustrate that a hydraulic disconnection occurs within 1-2 weeks of the last rain. Hydraulic disconnection is characterized by an accumulating moisture deficit in the soil and upper epikarst where the bulk of the root zone is located. This dry zone grows over time if there is little or no precipitation, requiring increasingly more water to re-establish a hydraulic connection between the surface and groundwater. If a subsequent precipitation event is insufficient to overcome the accumulated moisture deficit, infiltrating water cannot "break-through" into deeper regions of the epikarst, even though regions below the dry zone may still be draining and producing drips.

We determined the precipitation threshold for break-through in September 2011, at the peak of an exceptionally severe drought, at McCarty Cave. We applied the equivalent of a four-hour long, $100 \mathrm{~mm}$ rainfall event, five times during a nine-day period, over a $60 \mathrm{~m}^{2}$ area lying $\sim 4.0 \mathrm{~m}$ directly above the drip sites in the cave. The rate of application was relatively slow compared to typical rain events in central Texas, which sometimes produce as much as $80 \mathrm{~mm}$ in as little as 15 minutes (pers. obs.). In our experiment, $520 \mathrm{~mm}$ of artificial precipitation were required before we saw a response; a sharp increase in drip rate that was maintained at elevated rates first by continued application of water, and later by natural precipitation events over the following several months. Consistent with our earlier observations of natural precipitation events, vegetation recovered rapidly (visibly greening) within days of the first water application, long before moisture reached the cave. The break-through threshold of $520 \mathrm{~mm}$, equivalent to almost $60 \%$ of aver- age annual precipitation, may have been an extreme upper limit, since it was obtained during a time of record drought conditions in Texas.

Surprisingly, we observed that the accumulated moisture deficit controlled not only diffuse and direct infiltration, but also macropore flow during overland flow conditions. After the 2011 drought, in which only $210 \mathrm{~mm}$ of rain fell over a period of 390 days, a single high-intensity precipitation event of $70 \mathrm{~mm}$ produced no measurable response at any of the in-cave drip sites. Under no antecedent conditions has a precipitation event smaller than $5 \mathrm{~mm}$ resulted in an in-cave response.

We analyzed data from our third field site at CWAN to predict how much precipitation is required for a recharge response to occur after varying antecedent conditions. We used a logistic regression model with data from three in-cave discharge sites ranging from the main stream to a matrix- and fracture-dominated drip. This technique models the probability of a binary response $([1,0]$, or $[$ Yes, No]) using continuous predictor variables. We tested a variety of environmental variables in various combinations and used the sample size corrected Akaike Information Criterion (AICc) to select the best model. Predictor variables included cumulative PenmanMonteith Potential Evapotranspiration (PET) for $2-28$ weeks, incremented in two-week intervals, the amount of precipitation in a single event, soil moisture prior to a precipitation event, the length of a precipitation event (as a measure of intensity), and discharge at a site immediately prior to a rain event.

A mixed effect model for data from the three sites incorporating the 14 week sum of PET, soil moisture prior to a rain event, and sum of precipitation during a single event, was able to predict with $88.7 \%$ accuracy $(\mathrm{n}=115)$ whether or not a recharge response occurred as a result of a precipitation event (Gerard 2012). We validated this model by parameterizing a mixed effect model with a randomly selected half of the full dataset from the three sites $(\mathrm{n}=57$, accuracy $=87.7 \%)$, and used it to predict the remaining half of the data $(\mathrm{n}=58$, accuracy $=91.4 \%$ ). These results indicate that the model has similar predictive power outside of the data used to build it, and the high level of accuracy and consistency across data sets suggests that infiltration and recharge at this site, and possibly quite generally, are controlled by relatively simple, quantifiable meteorological variables. aquifer

The epikarst as a variable saturated and perched

At CWAN, between September 2009 and late 2012, we observed a variety of hydrogeologic responses to natural precipitation. These included fluctuations in drip rates on daily, seasonal, or longer time scales, likely associated with drainage from large open fissures at the 


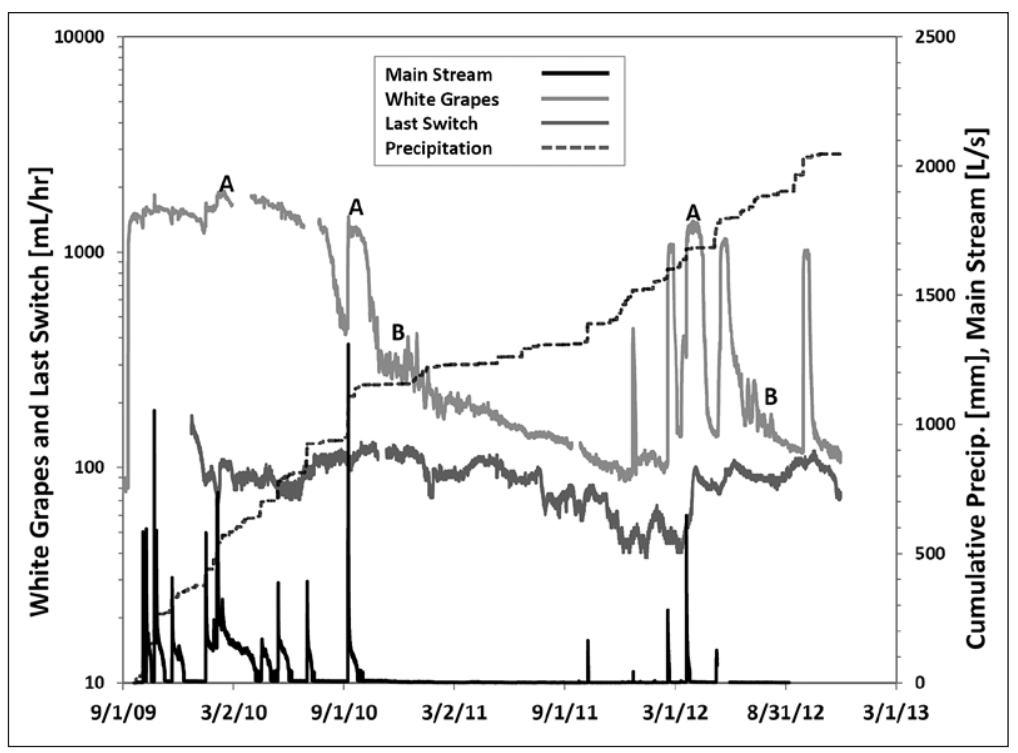

Fig. 3: Hydrographs for the White Grapes and Last Switch drip sites, and the Main Stream discharge site, in CWAN over a three year period, and cumulative precipitation above the cave. Regions marked with 'A' illustrate a plateau in drip rates that is maintained at $>1000 \mathrm{~mL} / \mathrm{hr}$ at the White Grapes Site prior to behavior attributed to the drainage of a perched aquifer (sudden declines in drip rate after 'plateaus' marked A). Large scale 'noise' in regions marked ' $B$ ' is attributed to barometric pressure effects on drip rates from variably saturated fracture/matrix. The Last Switch data represent drip flow dominated by matrix flow, Main Stream represents both base flow and direct recharge via conduits, and White Grapes represents a mixture of rapid direct recharge, perched aquifer drainage, and drainage from matrix and fracture storage. Gaps represent missing data due to instrument or logger failure. surface receiving water through overland flow, from perched, variably saturated epikarstic aquifers, and from the rock matrix, respectively. These observations support the conceptual model put forth by some researchers (Williams 1983; Klimchouk 2004) that describes the epikarst as a variably saturated fractured system with perched aquifers draining to underlying conduits via widely spaced large fractures and shafts. For example, we found evidence for a perched aquifer in the two-phase discharge dynamics of White Grapes drip at CWAN. This drip site is characterized by rapid increases in discharge after rain, followed by initially high and exponentially decreasing flow (periods of $>1000 \mathrm{~mL} / \mathrm{hr}$ marked 'A' in Fig. 3), a rapid decrease in discharge rates to $300 \mathrm{ml} / \mathrm{hr}$, and finally by exponentially decreasing flow with a flatter recession slope than before. The rapid decrease suggests sudden depletion of storage in a perched and highly transmissive aquifer.

However, we also found physical and hydrologic evidence of long-term storage in matrix and fracture/bedding plane porosity, which is characteristic of the region's Cretaceous limestones. Bedrock exposed in natural cave passages and broken or blasted outcrops at all three sites reveals high matrix and vuggy porosity (when compared to typical Paleozoic carbonates). Evidence supporting matrix/fracture/bedding storage was found in several sets of drip data (Fig. 3), where drips continued to flow, albeit with exponentially decreasing rates during the 390 days of drought. In that time, only one precipitation event caused a measurable recharge response at any of

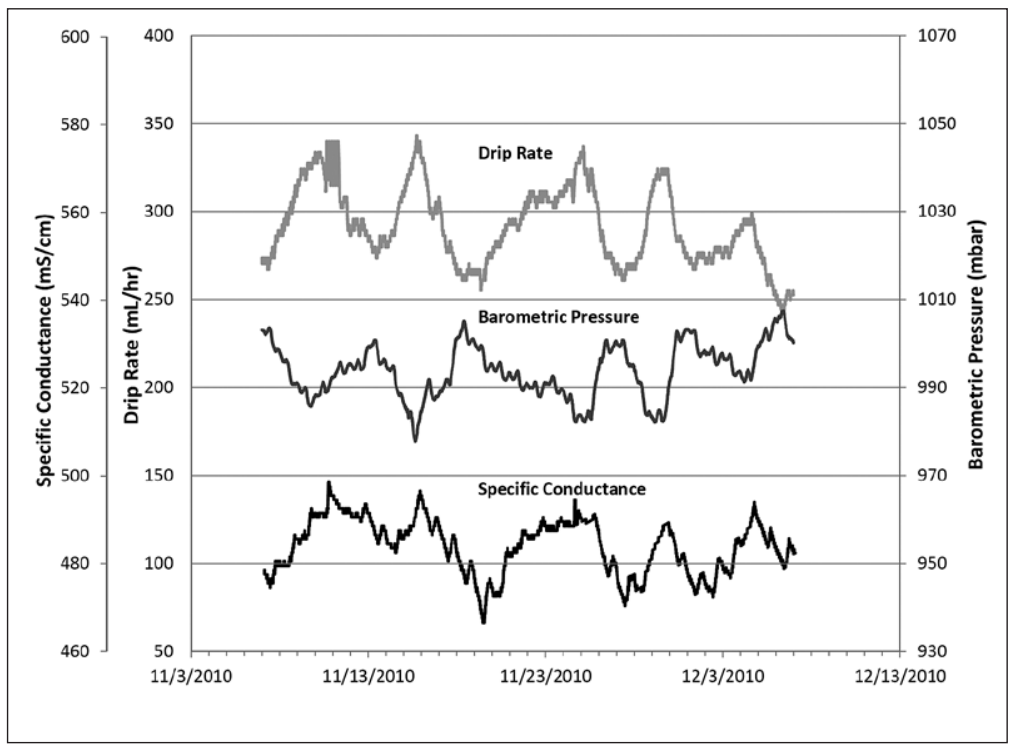

Fig. 4: A portion of CWAN White Grapes drip data illustrating relationships between changes in drip rate, barometric pressure, and specific conductance that support our hypothesis of gasses trapped in a variably saturated perched aquifer. Changes in pressure cause gas volumes to expand and contract, forcing water into (low SC drip periods) and out of fractures and vuggy porosity (high SC periods). 
the sites (a $70 \mathrm{~mm}$ rainfall caused a small overland flow/ direct recharge response at Main Stream on September 28, 2012). Thus, soil and upper epikarst storage was so depleted that almost no precipitation event passed through to contribute to deep infiltration and drainage. However, drips sites remained active, suggesting a highly persistent source of water in deeper matrix/fracture storage.

A second line of evidence for storage in matrix and fractures is found in portions of the White Grapes hydrograph data marked 'B' in Fig. 3 that appear 'noisy'. Attempting to explain these high-frequency signals, we discovered inverse relationships between barometric pressure, drip rate, and specific conductivity (SC) (Fig. 4). To our knowledge, this phenomenon has only been reported in a few previous drip studies (Genty and Deflandre 1998), but we found these signals at all drip sites and the main stream site in CWAN. Thus, the phenomenon seems to be pervasive and possibly driven by ubiquitous processes that may have been overlooked or ignored in other karst studies.

We recently proposed a simple model to explain the inverse relationship between drip rate and barometric pressure based on a mechanism involving variable saturation of the epikarst (Gerard 2012). Because the epikarst is part of the unsaturated zone, matrix, fracture, and small perched aquifers within it are subject to spatial and temporal variation in saturation. As epikarst ma- trix and fractures drain during drought, gasses replace water in the voids. Then, during recharge events, a rising perched water table traps gas pockets in dead-end fractures and vuggy porosity. With atmospheric pressure $\left(\mathrm{P}_{\text {atm }}\right)$ changes at the surface synchronously affecting pressure changes in the cave (though with a slightly damped signal), trapped gas pockets compress or expand in response to increases or decreases in $\mathrm{P}_{\mathrm{atm}}$. When $\mathrm{P}_{\mathrm{atm}}$ increases, gas pockets compress and water moves from main flow paths into dead-end fractures and vugs. As $\mathrm{P}_{\text {atm }}$ decreases, gas pockets expand and water is pushed back into the main flow paths from where some fraction drains out and reaches the drip monitoring site. In effect, the periodic fluctuation between gas compression and expansion pumps water into and out of dead-end compartments, explaining the inverse relationship between $\mathrm{P}_{\text {atm }}$ and drip rate.

If this model is correct, drips should have higher SC during periods of low $\mathrm{P}_{\text {atm }}$ when water is pushed out of the dead-end compartments. This is because this water will have had longer residence time in dead-end compartments (relative to the main flow paths) and increased time to dissolve rock. We tested this prediction and found it to be supported by the data (Fig. 4). Thus, drip rate dynamics are consistent with the lower regions of the epikarst functioning like a variably saturated, perched aquifer.

\section{CONCLUSIONS}

\section{THE EPIKARST AS A CRITICAL ZONE}

Our work in the Central Texas Hill Country has revealed an epikarst system that is controlled by complex interactions between physical, hydrogeochemical and biological processes. The biological dimension is often overlooked in karst research, but we find that a detailed understanding of karst ecohydrology is critical to predicting the dynamics of epikarst drainage and storage, and subsequent recharge to the aquifer.

For future research, we therefore promote a conceptual model of the epikarst system as an integrated critical zone, extending from the treetop to the base of the epikarst, with multiple internal interactions and feedbacks. Within this critical zone, trees in the Edwards Plateau primarily access soil and shallow epikarst water within the upper one to two meters of the surface. When cumulative precipitation overcomes any accumulated moisture deficit within this zone, infiltrating water moves below this depth and is essentially inaccessible to evapo- transpiration. It then contributes to a deeper and wellmixed storage compartment in which matrix and fracture porosity and permeability dominate, and residence times are probably on the order of several years or more. This variably (temporally and spatially) saturated zone extends from the base of the rooting zone downward to the regional water table, and within this range, some areas may also contain one or more perched aquifers.

Our study sites are representative of much of the Central Texas Hill Country where Edwards or Glen Rose Fm. carbonates outcrop, providing a foundation for future studies in the region. In ongoing and future research, we seek to apply and further refine the methodologies and models we developed for site- to small drainage basin-scales and apply them to larger karstic drainage basins in the Hill Country. Further, we plan to explore the role of epikarst and variation in its properties across the landscape in vegetation response to extreme climatic events, exemplified by the Texas Drought of 2011. 
The potential effects of barometric pressure on rates of epikarst evolution is another area of continuing research interest. How important is the periodic pumping of fluid into and out of dead-end compartments for solute transport out of the epikarst and into the lower conduit system?

\section{ACKNOWLEDGMENTS}

We thank landowners Jim and Shannon Brotherton for allowing unlimited access to McCarty Cave, Tom Summers (owner) and Mike Burrell (Manager) for allowing and facilitating access to CWAN, Matthew L. Cooksey and Chris Thibodaux for allowing access to Headquarters Cave and Camp Bullis, and ZARA Environmental for sharing drip data at Headquarters Cave. Thanks also to Philip Ramirez, Gabrielle Timmins, Benjamin Tobin, Benjamin Hutchins, Jacob Martin, and many others for their assistance in installing and maintaining equipment, and collecting samples above and below ground. Funding for this research was provided in part by a State of Texas THECB ARP grant (Project \# 003615-0021-2007), and a USGS 104g grant (Award \# G09AP00147).

\section{REFERENCES}

Arbel, Y., Greenbaum, N., Lange, J. \& M. Inbar, 2010: Infiltration processes and flow rates in developed karst vadose zone using tracers in cave drips. - Earth Surface Processes and Landforms, 35, 1682-1693.

Deng, Y., Jiang, Z.C. \& X.M. Qin, 2012: Water source partitioning among trees growing on carbonate rock in a subtropical region of Guangxi, China. Environmental Earth Sciences, 66(2), 635-640.

Dixon, R., 2000: Climatology of the Freeman Ranch, Hays County, Texas. Freeman Ranch Publication Series No 3-2000, pp 2-3, Southwest State University, San Marcos, Texas: 2-3.

Ehleringer, J., Roden, J. \& T. Dawson, 2000: Assessing ecosystem level water relations through stableisotope ratio analysis. Methods in Ecosystem Science. O. Sala, R. Jackson, H. Mooney and R. Howarth. New York, Springer: 181-214.

Estrada-Medina, H., Graham, R.C., Allen, M.F., Jimenez-Osornio, J.J. \& S. Robles-Casolco, 2013: The importance of limestone bedrock and dissolution karst features on tree root distribution in northern Yucatan, Mexico. - Plant and Soil, 362(1-2), 37-50.

Genty, D. \& G. Deflandre, 1998: Drip flow variations under a stalactite of the Père Noël cave (Belgium). Evidence of seasonal variations and air pressure constraints. - Journal of Hydrology, 211, 208-232.

Gerard, B., 2012: Effects of Environmental Parameters and Precipitation Dynamics on Infiltration and Recharge into the Trinity Aquifer of Central Texas. Department of Biology. San Marcos, Texas State University. M.S.: 61.
Gonfiantini, R., 1978: Standards for Stable Isotope Measurements in Natural Compounds. - Nature, 271(5645), 534-536.

Granier, A., 1985: A New Method of Sap Flow Measurement in Tree Stems. - Annales Des Sciences Forestieres, 42(2), 193-200.

Heilman, J.L., McInnes, K.J., Kjelgaard, J.F., Owens, M.K. \& S. Schwinning, 2009: Energy balance and water use in a subtropical karst woodland on the Edwards Plateau, Texas. - Journal of Hydrology, 373, 426-435.

Jackson, R.B., Moore, L.A., Hoffman, W.A., Pockman, W.T. \& C.R. Linder, 1999: Ecosystem rooting depth determined with caves and DNA. - Proceedings of the National Academy of Sciences of the United States of America, 96, 11387-11392.

JMP, 1989-2007: Version 9, SAS Institute Inc. Cary, NC. Jones, W.K., Culver, D.C. \& J.S. Herman, 2003: In: Introduction. Epikarst, Shepherdstown, WV, Karst Waters Institute.

Klimchouk, A.B., 2004: Towards defining, delimiting and classifying epikarst: Its origin, processes and variants of geomorphic evolution. - Speleogenesis and Evolution of Karst Aquifers www.speleogenesis.info, 2(1).

Kukowski, K.R., Schwinning, S. \& B.F. Schwartz, 2013: Hydraulic responses to extreme drought conditions in three co-dominant tree species in shallow soil over bedrock. Oecologia 171:819-830. 
Kuniansky, E.L. \& K.Q. Holligan, 1994: Simulations of flow in the Edwards-Trinity aquifer system and contiguous hydraulically connected units, west-central Texas. 93-4039. W.-R. I. Report, U.S. Geological Survey. 93-4039: 40.

Lee, E.S. \& N.C. Krothe, 2001: A four-component mixing model for water in a karst terrain in south-central Indiana, USA. Using solute concentration and stable isotopes as tracers.- Chemical Geology, 179, 129-143.

Mace, R.E., Chowdhury, A.H., Anaya, R. \& S.C. Way, 2000: Groundwater Availability of the Trinity Aquifer, Hill Country Area, Texas: Numerical Simulations Through 2050., Texas Water Development Board. Report: 119.

Mangin, A., 1975: Contribution a l'etude hydrodynamique des aquifers karstiques: DES thesis, Univ. Dijon, France, (Ann, Speleo. 1974, v. 29, nos. 3 and 4, 1975, v. 30, n. 1). DES.

Nie, Y.P., Chen, H.S., Wang, K.L., Tan, W., Deng, P.Y. \& J. Yang, 2011: Seasonal water use patterns of woody species growing on the continuous dolostone outcrops and nearby thin soils in subtropical China.Plant and Soil, 341(1-2), 399-412.

NSF, 2012. Critical Zone Observatories (CZO). Retrieved 12-28-2012, 2012, from http://www.nsf.gov/ pubs/2012/nsf12575/nsf12575.htm.

Querejeta, J.I., Estrada-Medina, H., Allen, M.F. \& J.J. Jimenez-Osornio, 2007: Water source partitioning among trees growing on shallow karst soils in a seasonally dry tropical climate.- Oecologia, 152(1), 26-36.

Querejeta, J.I., Estrada-Medina, H., Allen, M.F., Jimenez-Osornio, J.J. \& R. Ruenes, 2006: Utilization of bedrock water by Brosimum alicastrum trees growing on shallow soil atop limestone in a dry tropical climate.- Plant and Soil, 287(1-2), 187-197.
R Development Core Team, 2012: A Language and environment for statistical computing. Vienna, Austria, from http://www.R-project.org.

Rong, L., Chen, X., Chen, H., Wang, S.J. \& X.L. Du, 2011: Isotopic analysis of water sources of mountainous plant uptake in a karst plateau of southwest China.Hydrological Processes, 25(23), 3666-3675.

Schwinning, S., 2008: The water relations of two evergreen tree species in a karst savanna.- Oecologia, 158, 373-383.

Schwinning, S., 2010: Ecohydrology Bearings - Invited Commentary: The ecohydrology of roots in rocks.Ecohydrology, 3, 238-245.

Smart, P. L. \& H. Friederich, 1986: In: Water movement and storage in the unsaturated zone of a maturely karstified carbonate aquifer, Mendip Hills, England. Proceedings of the Environmental Problems in Karst Terranes and their Solutions Conference, Dublin, Ohio, National Water Well Association.

Van Auken, O.W., 2000: Shrub invasion of North American semiarid grasslands.- Annual Review of Ecology and Systematics, 31, 197-215.

Veni, G., 1994: Geomorphology, Hydrogeology, Geochemistry, and Evolution of the Karstic Lower Glen Rose Aquifer, South-central Texas. Department of Geosciences, Pennsylvania State University. Doctoral Dissertation: 721.

Williams, P.W., 1983: The role of the subcutaneous zone in karst hydrology.- Journal of Hydrology, 61, $45-67$. 